\title{
Construction of the offshore works for the cooling water intake at Moni Power Station
}

N. A. WILSON

Mr J. K. Pawulski, Senior Engineer, Rofe and Rafferty

I should like to ask Mr Wilson if consideration was given to the use of precast concrete culverts as an economic alternative to the in situ concrete. By the use of a combination of precast concrete culverts and tremie concrete top slab, the expensive operation of keeping the cofferdams dry could have been considerably reduced and, consequently, the time of construction substantially shortened.

\section{Mr N. A. Wilson}

Mr Pawulski has raised an interesting point in his reference to precast concrete culverts; in the light of the trouble encountered in driving the inshore cofferdams and in casting structural concrete against sheet piling it can now be argued that precasting the culverts might have been a better approach.

38. However, when methods of construetion were being considered in the pretender stage of the job the conditions appeared to be ideal for in situ construction within cofferdams. It was also felt that the work would progress more quickly if the piles were not withdrawn for re-use and so would also be available to anchor the culverts against flotation during maintenance. A further advantage which suggested itself was the saving of external formwork if the concrete was cast directly against the piles.

39. South of Bay 1 the depth of the sand on the sea bed would have been adequate for the excavation required to accommodate precast culvert sections. However, the presence of rock above formation level in Bay 1 meant that excavation in that length would have had to be done within a cofferdam.

Paper published: Proc. Instn civ. Engrs, 1969, 43 (July) 381-396. 